\title{
Acuerdos de cooperación y bases militares en territorio extranjero: ¿un “acto de agresión”...?*
}

\section{Cooperation Agreements and Military Bases in Foreign Territory: An “Act of Aggression”...?}

\section{Rafael A. Prieto Sanjuán**}

\begin{abstract}
Sumario: I. A manera de introducción. II. Aproximación jurídica a las alianzas defensivas. III. Atribución de hechos que podrían constituir un acto de agresión: la cuestión del control. IV. Conclusión.
\end{abstract}

* Artículo recibido el 20 de enero de 2011 y aceptado para su publicación el 26 de julio de 2011.

** El presente artículo constituye un avance del proyecto de investigación denominado "Uso de la fuerza y conducción de hostilidades en derecho internacional", inicialmente presentado como ponencia en el Seminario conmemorativo del décimo aniversario del Anuario Mexicano de Derecho Internacional y el Primer Congreso de la Sociedad Latinoamericana para el Derecho Internacional, celebrado en el Instituto de Investigaciones Jurídicas de la UNAM, los días 8 y 9 de septiembre de 2010. Mi profundo agradecimiento a sus directores, así como al auditorio y a los pares evaluadores, cuyas observaciones contribuyeron sensiblemente a la reflexión del autor. Sin embargo, cualquier imprecisión o error en su contenido, no podrían ser atribuibles sino al autor de este ensayo.

Doctor en Derecho (París II); magíster en Derecho internacional (ibíd.), en Estudios Latinoamericanos (París III) y en Estudios Estratégicos (París XIII). Profesor de la Universidad Militar Nueva Granada y de la Pontificia Universidad Javeriana, Bogotá, donde dirige la línea de investigación en derechos humanos, derecho internacional humanitario y derecho penal internacional. También ha sido profesor, conferencista y/o investigador invitado por las Universidades Complutense, París Nanterre, Caen (Francia), Bristol (Reino Unido) y la Academia de Derecho Internacional de La Haya, entre otras. 
RESUMEN: Recientes acuerdos de cooperación que implican el ejercicio extraterritorial de la competencia del Estado en materia de defensa y seguridad han dado pie a la polémica relativa a potenciales actos de agresión contra terceros. Sin embargo, antes de profundizar en asuntos propios de la política, es necesario precisar el significado jurídico de ciertos conceptos, esencialmente de orden convencional. Aun cuando no sea nada nuevo, trataremos de dejar en claro que este tipo de acuerdos siempre tendrá un carácter lícito mientras se inscriban en el marco del derecho internacional. Ahora, si los elementos militares de un determinado Estado sobre el territorio de otro llegasen a emplearse con un objetivo diferente al convenio en cuestión, o para cometer un acto de agresión contra un tercer Estado, deberán estudiarse cuidadosamente los aspectos de atribución o imputación, con el ánimo de establecer la eventual responsabilidad de las partes involucradas.

Palabras clave: acuerdos de cooperación, bases militares, operaciones extraterritoriales, agresión, responsabilidad internacional

ABSTRACT: Recent cooperation agreements involving the exercise of extraterritorial jurisdiction of defense and security of the State, have given rise to controversy regarding potential acts of aggression against others. However, before delving into affairs of politics, it is necessary to clarify the legal meaning of certain concepts, essentially regarding conventional order. Although it is not new, we shall try to make it clear that such agreements will always have a lawful basis while enrolled in the framework of International Law. Now, if the military elements of one State in the territory of another one get employed with a different purpose to the agreement in question, or to commit an act of aggression against a third State, the aspects of attribution or allocation must be studied, in order to establish the eventual responsibility of the parties involved.

Descriptors: cooperation agreements, military bases, extraterritorial operations, aggression, international responsibility.

RÉSUMÉ:DES nouvelles accords de coopération qui impliquant l'exercice de la compétence extraterritoriale de la défense de l'Etat et la sécurité ont donné lieu à controverse au sujet d'éventuels actes d'agression contre les autres. Toutefois, avant de plonger dans des affaires de politique, il est nécessaire de clarifier le sens de certains concepts juridiques, essentiellement d'ordre conventionnel. Même s'il n'est pas quelque chose de nouveau, essayez de préciser que ces accords auront toujours une base légale alors qu'il est inscrit dans le cadre du droit international. Maintenant, si les éléments militaires d'un État sur le territoire d'autre viennent d'employer dans un but différent de l'accord en question, ou de commettre un acte d'agression contre un pays tiers, doivent être soigneusement étudiés les questions d'attribution ou de l'allocation aux Afin d'établir l'éventuelle responsabilité des parties concernées.

Mots clés: accords de coopération, bases militaires, opérations extraterritoriales, agression, responsabilité internationale. 


\section{A MANERA DE INTRODUCCIÓN}

1. Algunas observaciones preliminares sobre el uso de la fuerza en un Estado de derecho

Sin duda alguna, la figura de la agresión constituye una de las "[v]iolaciones graves de obligaciones emanadas de normas imperativas del derecho internacional general"' que puede ser atribuida al Estado, y también al individuo, como lo evidencia la Conferencia de revisión del Estatuto de la Corte Penal Internacional, reunida en Kampala el año pasado; pero, tanto sus contornos, como su contenido y consecuencias, es algo sobre lo cual no existe total acuerdo. ${ }^{2}$ Por supuesto, más allá de la discusión relativa a la autoría del hecho ilícito, así como la responsabilidad de los Estados involucrados en un acto de agresión, lo que se discute en el fondo es si en realidad estamos en un Estado de derecho, donde impera la ley por encima de la fuerza. ${ }^{3}$

1 Capítulo III del Proyecto de la Comisión de Derecho Internacional (CDI) sobre la Responsabilidad del Estado por hechos internacionalmente ilícitos, adoptado por la CDI en su 53o. periodo de sesiones (A/56/10) y anexado en la Resolución 56/83 de la Asamblea General de las Naciones Unidas [sobre la base del informe de la Sexta Comisión (A/56/589 y Corr.1)] adoptada en el curso de su quincuagésimo sexto periodo de sesiones (tema 162 del programa 01 47800), 85a. sesión plenaria del 12 de diciembre de 2001 (doc. A/RES/56/83 del 28 de enero de 2002). En adelante, será citado simplemente como "Proyecto sobre Responsabilidad".

Cfr. desde la Carta de las Naciones Unidas, de 1945, hasta la Conferencia de revisión del Estatuto de la Corte Penal Internacional, de 2010, pasando desde luego por la definición de la agresión, adoptada por la Asamblea General de las Naciones Unidas en 1974, aunque desde principios del siglo pasado la doctrina ya venía estudiado el tema. Véase, por ejemplo, la catalogación de 541 referencias bibliográficas sobre dicho sujeto en la Biblioteca del Palacio de la Paz [http:/ / www.ppl.nl] al 25 de mayo de 2011.

3 De hecho, ese fue el eje temático de nuestra Mesa de discusión (El Estado de Derecho Internacional: Más allá del Consejo de Seguridad) en el Seminario antes mencionado, supra nota * y, casualmente, en el volumen anterior de este Anuario, la preocupación de Arrocha Olabuenaga, Pablo, "Consideraciones sobre el Estado de derecho en el plano internacional", Anuario Mexicano de Derecho Internacional, vol. X, 2010, pp. 173-197. Cfr. entre otros, Ben Achour, Rafâa y Laghmani, Slim (dirs.), Le droit international à la croisée des chemins: force du droit et droit de la force, París, Pedone, 2004; Sriram, Chandra Lekha, Olga Martin-Ortega y Johanna Herman (ed.), Peacebuilding and Rule of Law in Africa: Just Peace?, Londres, Routledge 2011. 
Ahora bien, si entendemos el Estado de derecho como la existencia de una sociedad fundada en la norma jurídica, fácilmente podríamos inferir que dicha sociedad renuncia al uso de la violencia en favor de una rama u órgano específico del poder público, a quien se encomienda garantizar la seguridad e integridad de sus asociados. Bien sabemos que, en derecho interno, el monopolio de la violencia reposa en la cabeza del Estado, normalmente, bajo el control del Ejecutivo, es decir, de sus fuerzas armadas y de policía. Pero en derecho internacional (en adelante DI) dicho monopolio no ha sido hasta el momento sino un ideal o, al menos, cuando el Consejo de Seguridad de las Naciones Unidas (en adelante CS) lo ha tratado, ha sido de manera ocasional y absolutamente selectiva. En consecuencia, son los sujetos primigenios de la sociedad internacional — los Estados - quienes ostentan a priori el poder de interpretación, aplicación y limitación del uso de la fuerza. ${ }^{4}$

Así las cosas, en DI, el uso de la fuerza no tiene de monopolio sino las circunstancias concretas que habilitan al CS en el marco del capítulo VII de la Carta de las Naciones Unidas. Tan legítimo y lícito resulta el poder de calificación o constatación de una situación de agresión, así como la consecuente adopción de las medidas que impliquen el uso de la fuerza por parte del CS, como la interpretación y las medidas que un determinado Estado, o un grupo de Estados, adopta frente a una situación de similar naturaleza, por supuesto, de conformidad con el DI que ellos mismos han creado. ${ }^{5}$

Sin embargo, dado que no podríamos abarcar en este espacio todos los problemas relativos al uso de la fuerza en un Estado de derecho in-

4 Sin embargo, ¿la coexistencia de distintas legitimidades en el uso de la fuerza implicaría la denegación de un Estado de derecho? Pues, no. Se trata del ordenamiento jurídico que los sujetos de DI se han querido dar en función de su capacidad normativa. En consecuencia, no sería acertado razonar en términos de derecho interno las particularidades de una sociedad (actores y sujetos) regida por el DI (instituciones, obligaciones y mecanismos de resolución de conflictos).

${ }^{5}$ Lo que sucede en DI es que la norma no siempre es suficientemente explícita, lo que no implica ausencia de ésta; motivo por el cual, tampoco sería apropiado afirmar la inexistencia de un Estado de DI. Como lo acabamos de mencionar, los mecanismos de aplicación y sanción de la norma internacional no son los mismos del derecho interno (Di). Simplemente, los primeros, los del DI, son mucho más difusos o descentralizados y competitivos entre ellos que los últimos (los del Di). 
ternacional, la pregunta inicial y principal, la de saber si es posible una agresión por la vía de bases militares extraterritoriales, será respondida con un análisis conceptual del fenómeno (II) y, enseguida, realizando un examen acerca de la posible atribución de algunas hipótesis que podrían constituir un acto de agresión (III).

\section{APROXIMACIÓN JURÍDICA A LAS ALIANZAS DEFENSIVAS}

Se pensaría que la implantación de bases militares en territorio extranjero, mientras cuente con el consentimiento del Estado de acogida y, en la medida en que no se conciba como punta de lanza para atacar a otro Estado, no debería causar controversia alguna. ${ }^{6} \mathrm{~A}$ pesar de ello, acuerdos de cooperación militar como los celebrados entre países latinoamericanos y, sobre todo entre algunos de ellos y los Estados Unidos de América, han hecho surgir o resurgir un debate en el ámbito regional que nace de una relación bilateral y que merece algunas precisiones conceptuales. Quedan excluidas de nuestro estudio las organizaciones e iniciativas integradoras o multilaterales. ${ }^{7}$

Así, para responder a la cuestión de si la instalación de bases militares en el territorio de un Estado diferente al Estado de origen constituye una agresión, es necesario recordar la existencia y objeto de algunos de los acuerdos de cooperación vigentes en Latinoamérica (1). Segui-

6 Cfr. Harkavy, Robert E., Bases abroad: the global foreign military presence, Oxford, Oxford University Press, Stockholm International Peace Research Institute (SIPRI), 1989.

7 Además de los aspectos integradores más ambiciosos, como los de la OEA y la Conferencia de Ministros de Defensa de las Américas, encontramos de norte a sur del continente las siguientes iniciativas subregionales en materia de Defensa: Security and Prosperity Partnership of North America, Mérida, Sistema de la Integración Centroamericana-Subcomisión de Defensa, Conferencia de las Fuerzas Armadas Centroamericanas, Central America Regional Security Initiative, Regional Security System, Caribbean Basin Security Initiative, Caribbean Community, Alianza Bolivariana para los Pueblos de Nuestra América, Consejo de Defensa Suramericano de UNASUR, y Organización del Tratado de Cooperación Amazónica, además de la institucionalización de importantes foros como la Conferencia de Ejércitos Americanos, las Conferencias Navales Interamericanas y el Sistema de Cooperación entre las Fuerzas Aéreas Americanas. Véase Donadio, Marcela (dir.), Atlas comparativo de la defensa en América Latina y Caribe, Buenos Aires, Resdal, en especial, el capítulo 5 (Relaciones hemisféricas), pp. 70-75. 
damente, será menester ilustrar aquellas situaciones de presencia más o menos regular de las fuerzas armadas de un Estado, lo que se conoce de manera genérica como bases militares, en territorio extranjero (2).

\section{Acuerdos de cooperación o asistencia militar, defensa y seguridad}

Ante la rareza de situaciones que pudiesen implicar el uso de la fuerza entre los Estados de la región, ${ }^{8}$ bastante oportuna para nuestro estudio aparece la discusión surgida con ocasión de los acuerdos de cooperación militar celebrados entre Colombia y los Estados Unidos o entre estos y Aruba (Antillas Holandesas). No obstante, antes de echar un vistazo a algunos acuerdos estratégicos de cooperación militar o defensiva en América Latina (B) conviene precisar los conceptos de alianza y cooperación $(\mathrm{A})$.

\section{A. De los pactos y alianzas en general...}

Antes de abordar el tema de la cooperación militar, hay que recordar que, sobre la base de la voluntad y del respeto del DI, los Estados son libres de celebrar las alianzas políticas, tecnológicas o económicas, o de cualquier otra índole que bien les parezca. En este sentido, la estrategia que cada cual adopte puede tener una vocación integral o especializada, aun cuando difícilmente se conciba de manera aislada un solo campo o sector de la cooperación entre países aliados. Por ejemplo, no resultaría lógico que la cooperación en materia de derechos humanos se diera sin una determinada proyección y adopción de diversas medidas de carácter económico o, en dirección inversa, que la cooperación económica y el intercambio comercial se surta en desconocimiento del desarrollo social y algún grado de protección de los derechos fundamentales. De

8 Después de la “Guerra de las Malvinas", en 1982, el único conflicto armado de carácter internacional del que se tenga registro, fue aquel de carácter limítrofe y bastante fugaz entre Ecuador y Perú, también conocido como la Guerra del Cenepa o de Tiwinza, en 1995. Cfr. Palmer, David Scott, "Peru-Ecuador Border Conflict: Missed Opportunities, Misplaced Nationalism, and Multilateral Peacekeeping", Journal of Interamerican Studies andWorld Affairs, vol. 39, 1997, pp. 109-148. 
allí, las conocidas cláusulas de condicionalidad impuestas por países donantes o líderes de la cooperación internacional a los destinatarios de la asistencia técnica o financiera. ${ }^{9}$

Así, en la época de la denominada Guerra Fría, era evidente la alineación —alienación, dirían algunos — de los Estados de la región a uno de los dos campos de la confrontación ideológica. Es bien conocida, por ejemplo, la dependencia de todo el Cono Sur, así como buena parte de Centroamérica y del Caribe, hacia los Estados Unidos, y el apoyo de estos a los gobiernos de entonces para enfrentar la "amenaza comunista". ${ }^{10}$ El único reducto de esta dinámica — hasta el día de hoy — había sido Cuba, quien recibía todo el apoyo (en todas las áreas del desarrollo) de la antigua Unión Soviética, al igual que los demás países en el mundo con ascendente socialista. Tratándose de entidades no estatales (movimientos rebeldes o insurreccionales, o incluso de carácter terrorista), las demás actividades de apoyo y financiación de la causa "antiimperialista”, por supuesto, no eran oficiales. Es esta situación la que, entre otras cosas, conduce, de parte y parte, a la imposición de regímenes dictatoriales, a la respectiva insurgencia política y armada, pero sobre todo, a un importante retraso en el desarrollo de Latinoamérica.

9 Véase, entre otros, Pinelli, Cesare, "Conditioning Trade on Respect for Human Rights and Democratic Dilemmas and Challenges for International Organizations and the EU”, Revue Européenne de Droit Public, t. 7, 2005, núm. 3, pp. 1077-1093; Tirado Robles, Carmen, "La condicionalidad de los derechos humanos en la política comercial comunitaria", en Embid Irujo, Antonio (dir.), Comercio internacional y derechos humanos, Pamplona, Aranzadi, 2007, pp. 69-94, y Dusépulchre, Gaëlle, "De la conditionnalité démocratique à la gouvernance comme instrument de promotion des droits de l'Homme, de la démocratie et de l'État de droit”, en Rideau, Joël (dir.), Les droits fondamentaux dans l'Union européenne : dans le sillage de la Constitution européenne : en hommage à René-Jean Dupuy, 1918-1997, Bruselas, Bruylant, 2009, pp. 457-477.

10 Véase, por ejemplo, el acuerdo bilateral denominado Memorándum de entendimiento, suscrito entre Argentina y los Estados Unidos el 10 de mayo de 1964, relativo a la cooperación militar entre ambos gobiernos, el cual, "en el contexto de la renovada preocupación norteamericana por la manifestación de la amenaza comunista-castrista al interior de cada uno de los países latinoamericanos, ponía a disposición equipos militares, materiales y servicios”. Escudé, Carlos y Cisneros, Andrés (dirs.), Historia de las Relaciones Exteriores Argentinas, Consejo Argentino para las Relaciones Internacionales, Buenos Aires, Grupo Editor Latinoamericano, 2000, http: / / www.argentina-rree.com/13/13-041.htm. 
En resumen, después de las luchas de emancipación colonial, cuyos bicentenarios aún estamos conmemorando, las alianzas que existieron en América Latina fueron esencialmente de — nueva - dependencia, y no de verdadera integración. El fin de la Guerra Fría va a permitir ciertos procesos de transición que conducen a renegociar diferentes pactos $\mathrm{y}$ acuerdos con las antiguas potencias dominadoras, pero asimismo, a crear o relanzar acuerdos de cooperación entre Estados de la región o vecinos, y en condiciones de mayor equilibrio.

En materia de seguridad y defensa, es fácil constatar esta dinámica de pactos, alianzas y asistencia internacional. Por supuesto, hay intereses que desbordan los aspectos propios de la defensa nacional y la seguridad internacional, o que son plasmados de manera muy genérica en un acuerdo estratégico. Pero, si estamos evocando la multiplicidad y la interconectividad entre diversos intereses, no es sino con el ánimo de resaltar el porqué nos ocuparemos exclusivamente de la cuestión de la cooperación y asistencia militar, dada la necesidad de delimitar nuestra disertación. Algunas veces, podrá tratarse de un acuerdo de cooperación militar, complejo y duradero, y otras, de transferencia de tecnología o sólo de una transacción comercial.

\section{B. ... a la cooperación militar en América Latina y del Caribe}

Para garantizar el servicio público de defensa y seguridad, tanto en el plano nacional como internacional, podríamos comenzar con el ejemplo de Chile, quien, el 24 de agosto de 2007, celebró con Uruguay el Acuerdo de Cooperación en Materia de Defensa, ${ }^{11}$ así como el Memorando o Memorándum de Entendimiento (en adelante MDE) para la Cooperación en Materia de Defensa, firmado con Ecuador en 2002 y, con este mismo país, en 2010, el MDE en el campo de la industria de la defensa, para la modernización o coproducción de vehículos blindados livianos y de artillería antiaérea. ${ }^{12}$ Asimismo, para "fortalecer sus capacidades a través de acciones como entrenamiento, intercambio de ex-

\footnotetext{
11 Texto en: Uruguay, Poder Legislativo, http://www.parlamento.gub.uy/htmlstat/pl/acuer dos/acue-ap-34803.htm.

12 “Acuerdo de cooperación militar entre Ecuador y Chile”, El Mercurio, 22 noviembre de 2010 .
} 
periencias, conocimiento, venta de equipo, coproducción, transferencia de tecnología y asistencia técnica". ${ }^{13}$

Con Estados fuera del continente, se destaca el Acuerdo de Cooperación entre Chile y Turquía sobre Entrenamiento Militar e Industria de Defensa, Tecnología y Ciencia, celebrado en Ankara, el 19 de abril de 2004. ${ }^{14}$ Con Sudáfrica, el MDE sobre Cooperación en Materia de Defensa, suscrito el 11 de octubre de 2006. ${ }^{15}$ Mientras que con España, sobresalen varios memorandos del mismo orden: para la Cooperación en el Ámbito del Submarino Scorpene, Estatuto de Personal entre las dos Armadas para dicho programa, ambos de 1999, el Acuerdo Técnico "Júpiter" de Apoyo a la Armada de Chile y control del mismo programa ("Scorpène”), del año siguiente, y de nuevo, los MDE's de Cooperación en el Dominio Industrial y del Material y Equipamiento de Defensa, de 2004 y, en Materia de Perfeccionamiento Técnico Profesional, del siguiente año. ${ }^{16}$ En fin, con Francia, destacaremos cómo se buscó sellar el acuerdo militar a partir del cual se pudiesen desarrollar lazos industriales y de transferencias de tecnologías (similar al pactado con Brasil, infra), luego de declararse que "[h]emos desde hace mucho trabajado en un sistema de equipamiento conjunto en la Marina y de observación satelital pero queremos hacer muchos más". ${ }^{17}$

Por su parte, Argentina también ha suscrito un acuerdo de cooperación militar en materia de capacitación, formación militar, asesoría técnica y otros trabajos centrados en el nuevo rol de las fuerzas armadas de los dos países (con Honduras), el 2 de septiembre de 2006, ${ }^{18}$ al igual que con otros gobiernos fuera de América Latina: con Italia, un MDE

13 Ibidem. Véase asimismo el Acuerdo Bilateral de Cooperación en Defensa, suscrito con Brasil en diciembre de 2007.

14 Véase presentación del Gobierno a la Cámara de Diputados en el Boletín, núm. 3919-10.

15 En http: / / cl.vlex.com/vid/memorandum-entendimiento-traves-57648 182\#ixzz19RGb9Pnb.

16 Véase Listado acuerdos bilaterales, en el sitio del Ministerio de Defensa español, http: / / www.mde.es/Galerias / politica / armamento-material/ficheros/DGM_Mos_Bilaterales_Firmados.pdf.

17 AFP y EFE, 29 de octubre de 2009. Asimismo con Rusia, con quien se firmó un tratado de asociación y cooperación, y un acuerdo de cooperación militar el 15 de abril de 2009.

18 ACAN-EFE, 28 de septiembre de 2009. Véase los acuerdos similares suscritos con Bolivia (2006), Brasil (1997, 1999, 2002, 2003 y 2005), Chile (1995, 2001, 2005 y 2008), Ecuador (2007), El Salvador (2009), Paraguay (2007 y 2008), Perú (2006) y Uruguay (2010), en: Donadio, Marcela (dir.), Atlas Comparativo..., cit., p. 78. 
para la Cooperación y Asistencia Técnico-Logística en el Campo de Materiales para la Defensa, del 6 de octubre de 2010; ${ }^{19}$ con Sudáfrica, el 22 de noviembre de 2010, acuerdos que comprenden la Cooperación en Ciencia, Tecnología y Producción para la Defensa, con el objeto de trabajar en el establecimiento de operaciones combinadas y cooperar en “campañas antárticas, operaciones de mantenimiento de la paz, búsqueda y rescate en el Atlántico Sur e intercambio de alumnos”. ${ }^{20}$

Uruguay, a su vez, también ha celebrado convenios de cooperación en el ámbito de la defensa, el 20 de julio de 2010, con Brasil, para intensificar las relaciones entre ambos países y apoyarse recíprocamente en materiales, efectivos y acciones comunes. ${ }^{21}$ Con Argentina, el Acuerdo de Cooperación para la Defensa, con el objetivo de

fortalecer las relaciones entre ambas naciones, la creación de un dialogo político-estratégico, capacitación de personal civil de la defensa, cooperación militar, ejercicios combinados, operaciones conjuntas de paz de la ONU, formación, capacitación y desarrollo de actividades académicas, ciencia, tecnología y producción para la defensa. ${ }^{22}$

Acuerdo similar el que celebra Montevideo con Caracas en la "búsqueda de intereses comunes a fin de potenciar el intercambio material, profesional y la cooperación a nivel internacional”. ${ }^{23}$ Allí se establecen los ámbitos de cooperación e intercambio en áreas de capacitación y entrenamiento de personal, cooperación en ciencia y tecnología, apoyo logístico técnico-militar. Asimismo, el 16 de noviembre de 2010, se suscribió con Ecuador, un Acuerdo sobre Cooperación en el Ámbito de la Defensa, con el ánimo de "[p]romover la colaboración, compartir conocimientos y experiencias adquiridas en el campo de las operaciones, utilización de equipamiento en el cumplimiento de tareas inter-

19 En Infodefensa.com, 6 de octubre de 2010.

20 EFE, 20 de noviembre de 2010.

21 Ministerio de Defensa de Brasil, 4 de agosto 2010. Reproducido en el blog Máquina de Combate.

22 Acuerdo del 2 de junio de 2010, Ministerio de Defensa de Uruguay, nota de prensa, 20 de diciembre de 2010.

23 Idem. 
nacionales de mantenimiento de la paz, entre otros". ${ }^{24}$ En fin, fuera del continente, se anuncia la futura firma de un acuerdo de cooperación en material militar con Serbia, por ejemplo. ${ }^{25}$

El caso de Brasil es quizás el más significativo, por su deseo de consolidarse como potencia regional y de posicionarse a nivel mundial. Es por ello que ha llevado a cabo acuerdos con un importante número de Estados, desde el Cono Sur hasta el Norte del continente americano. Por citar apenas un par de ejemplos, con la República Dominicana, el Acuerdo de Cooperación Bilateral en Materia de Defensa y Seguridad, con el objetivo de intensificar las relaciones en dicha materia, suscrito el 4 de febrero de 2010. ${ }^{26}$ Con Perú, el Acuerdo Marco de Cooperación en Defensa, por medio del cual "ambos países desarrollarán una visión compartida en materia de defensa... identificarán temas e intereses comunes a nivel global, hemisférico y regional”. Se autoriza

el intercambio de información en inteligencia estratégica, en coordinación con su organismos de defensa... compartirán conocimientos y experiencias adquiridos en el campo de operaciones militares, así como en el uso de equipo castrense de origen nacional y extranjero. Al mismo tiempo, facilitará el cumplimiento de operaciones internacionales dirigidas a mantener la paz, promoverá acciones conjuntas de entrenamiento, instrucción militar, ejercicios combinados y acción cívica. ${ }^{27}$

Por fuera del continente, el 9 de diciembre de 2010, Brasil firmó con España un Acuerdo de Cooperación en el Ámbito de la Defensa, por

24 Ministerio de Defensa de Ecuador. Reproducido en el blog Máquina de Combate.

25 EFE, 28 de septiembre de 2010. Acuerdo que se sumaría a los celebrados con España, Rusia, China y Sudáfrica. Véase Donadio, Marcela (dir.), Atlas Comparativo..., cit., p. 79.

26 En Infodefensa.com, misma fecha.

27 Idem. Ver resolución legislativa de ratificación núm. 29348, del 8 de abril de 2009, publicada en el diario oficial El Peruano, dando continuidad al Memorándum para la Vigilancia y Cooperación de la Amazonía (2003), al Acuerdo Marco de Cooperación, y al Mecanismo de Consulta y Cooperación, ambos de 2006. De igual forma, notaremos que Brasilia ha celebrado acuerdos o convenios de similar naturaleza con Bolivia (2007), Colombia (2003 y 2008), Ecuador (2007), El Salvador (2007), Guatemala (2006), Guyana (), Honduras (2007), Chile (2007). Paraguay $(1995,2007)$ y Uruguay (supra, 2010). Cfr. Donadio, Marcela (dir.), Atlas Comparativo..., cit., p. 79. 
medio del cual los dos Estados se comprometen a promover y fortalecer la colaboración en áreas de planificación, investigación y desarrollo, apoyo logístico y adquisición de productos y servicios de defensa. ${ }^{28} \mathrm{Con}$ el Reino Unido, el Defence Cooperation Treaty, del 14 de septiembre de 2010, que sirve para abrir la puerta a nuevas compras de equipamiento y tecnología bélicas, en un esfuerzo más por reforzar su industria de producción militar ${ }^{29} \mathrm{y}$, de manera más especializada, con la Marina Británica, un documento de orientación marítima de seguridad conjunta, que incluye el intercambio en materia de información, entrenamiento naval, hidrografía y logística, con el objetivo de lograr una mayor cooperación entre la Royal Navy y la Marina de Brasil. ${ }^{30}$ Pero, quizás, el acuerdo que tuvo mayor resonancia, fue el firmado con París un año atrás, ${ }^{31}$ por el hecho de implicar transferencia de tecnología militar, en particular, para la construcción de un submarino nuclear en territorio brasileño. A ese propósito, no sobra recordar que hace más de cuatro décadas el "continente latinoamericano" en bloque se comprometió "a abstenerse de realizar, fomentar o autorizar, directa o indirectamente, el ensayo, el uso, la fabricación, la producción, la posesión o el dominio

\footnotetext{
28 Asimismo, el acuerdo prevé la promoción de "la cooperación científica y tecnológica y colaborarán en asuntos relacionados con la adquisición y utilización de equipos y sistemas militares de origen nacional y extranjero. Los dos países, además, compartirán conocimientos y experiencia en el ámbito operativo y de participación en misiones internacionales de paz, y fomentarán la realización de actividades conjuntas de entrenamiento, instrucción militar y ejercicios militares combinados”. En Infodefensa.com, 9 de diciembre del 2010.

29 Véase Comunicados de ambos Ministerios y notas de prensa de la AFP, reproducidas en Infodefensa.com y en el blog Máquina de Combate, entre otros.

30 En Infodefensa.com, 29 de noviembre de 2010.

31 Acuerdos alcanzados con ocasión de la visita del presidente Sarkozy a Brasil en diciembre del 2008 — y, previamente, en febrero del mismo año en la Guyana francesa-, pero formalizados sólo hasta el 7 de septiembre de 2009, día de la Independencia del Brasil. Ver despachos de la AFP, Reuters y DPA, así como la nota "Brasil firmó con Francia el mayor acuerdo militar de los últimos 50 años”, http://www.infobae.com/notas/nota_imprimir. php?Idx $=470775$, 8 de septiembre de 2009. Además de España, Francia y Reino Unido, Brasilia también ha celebrado acuerdos con Alemania, China, Estados Unidos, India, Italia, Corea del Sur, Polonia, República Checa, Rusia, Serbia, Sudáfrica, Turquía y Ucrania, algunos de los cuales también incluyen ambiciosos programas de compras de tecnología militar para la posterior producción de armamento en Brasil. Cfr. Donadio, Marcela (dir.), Atlas Comparativo..., cit., p. 79.
} 
de toda arma nuclear o de participar en ello de cualquier manera" (énfasis añadido). ${ }^{32}$

Por su parte, Estados como Bolivia, con ambiciones militares mucho más modestas que las de sus vecinos, han celebrado convenios de cooperación con otros países de la subregión, como por ejemplo con Ecuador, con el ánimo de "fortalece[r] la confianza y el intercambio académico, de seguridad y defensa [asistencia, cooperación técnica y educativa] entre los países andinos". ${ }^{33}$ Adicionalmente, en la media que nadie desconoce el enorme liderazgo — dependencia — que ejerce Venezuela sobre el gobierno del altiplano, es comprensible que La Paz también haya firmado con Caracas un Memorando de Entendimiento en Materia de Seguridad y Defensa, el cual comprende cooperación en asuntos marítimos, aviación militar y capacitación. ${ }^{34}$ En fin, Bolivia tampoco ha podido evitar la tentación de aceptar la "cooperación” extra continental, tal y como rinden testimonio los acuerdos celebrados con Rusia en materia de cooperación militar y antidrogas ${ }^{35}$ o la ampliación del Protocolo de Amistad y Cooperación que mantiene con China ${ }^{36}$ en las áreas de defensa, fuerzas armadas, apoyo al desarrollo científico-tecnológico y el "establecimiento de contactos culturales".

32 Artículo 1o., núm. 2 del Tratado para la Prohibición de las Armas Nucleares en la América Latina y el Caribe (Tratado de Tlatelolco de 1967). No obstante, ya habíamos notado este hecho en su oportunidad sin despertar mayor reacción. Prieto Sanjuán, Rafael A. "Adeus, Tlatelolco. Bonjour le TNP”, El Espectador, 15 de septiembre de 2009, http://www.elespecta dor.com/node/161639/print. Cfr. Frayssinet, Fabiana, "Acuerdo militar con Francia favorece multipolarización”, IPS Inter Press Service, 8 de septiembre de 2009, http: / / ipsnoticias.net / print. asp?idnews $=93258$.

33 Según el despacho de la agencia EFE, del 6 de junio de 2008, y siguiendo el documento aludido, la cooperación "podrá realizarse a través de modalidades de intercambio y becas en escuelas de formación básica, de perfeccionamiento y especialización para oficiales y personal de tropa; intercambio de personal profesional y técnico; creación de grupos de trabajo e investigación; ejecución de proyectos mutuos; intercambio de experiencias; asesoría técnica y otras que se considere necesario".

34 Instrumento que también abriría la posibilidad de instalar una Escuela Naval en Bolivia. EFE, 22 de mayo de 2008.

35 De acuerdo con la agencia de noticias Interfax (16 de febrero de 2009), quien retoma las palabras del director del Servicio de Cooperación Militar Técnica Federal de Rusia, "Moscú podría emitir un préstamo a Bolivia para comprar armas hechas en Rusia", así como "proveer varios helicópteros... Si el préstamo es otorgado, será aplicable a todo tipo de equipo militar”.

36 Prensa, 17 de agosto de 2010. 
Por su parte, el gobierno venezolano, uno de los principales opositores a la influencia estadounidense en la región, no podía dejar de aprovechar sus recursos financieros (originados esencialmente en la producción petrolera) para ejercer su propia influencia sobre otros países como Ecuador y Nicaragua, o incluso sobre Argentina o el mismo Brasil, ${ }^{37}$ con quienes ha celebrado diversos acuerdos en un inocultable deseo de convertirse en potencia regional. ${ }^{38}$ Pero lo que más llama la atención de Caracas es la acción provocadora al entablar relaciones con regímenes, cuando no contrarios a los intereses de Washington (Corea del Norte, Irán, Libia, Siria y Sudán), por lo menos seriamente competitivos de su hegemonía. Así, por ejemplo, en materia militar, notaremos cómo, el 27 de julio de 2010, se firmó un Nuevo Estatuto sobre la Cooperación Militar y Técnica con Rusia, como marco para llevar a cabo nuevas compras de armamento, realización de maniobras conjuntas e intercambio de tecnología. ${ }^{39}$

Podríamos continuar nuestro recorrido hacia el norte, por Centroamérica y el Caribe, pero sin duda que no encontraríamos diferencias sustanciales, incluso con relación al equilibrio o desequilibrio de capacidades e intereses, pero es algo que no nos corresponde examinar en este trabajo. De hecho, la reciprocidad de derechos y obligaciones entre las partes contratantes es algo que pertenece al resorte de cada Estado, a su capacidad de negociación y aplicación de los tratados en DI. Interesémonos mejor en uno de los aspectos más discutidos en los últimos tiempos, a saber, el de la presencia física de agentes militares en territorio extranjero, no sin antes resumir esquemáticamente lo hasta ahora estudiado.

37 Entre los famosos cables revelados por WikiLeaks, llama por ejemplo la atención la preocupación de Estados Unidos por la manipulación de la que habría sido objeto el presidente Lula da Silva por parte de su homólogo venezolano. Véase Meirelles Passos, José, "Para EUA, Lula é 'absurdamente brando' com Morales, revela WikiLeaks”, O Globo, 30 de diciembre de 2010, http: / /oglobo.globo.com / mundo/mat/2010/12 /29/para-eua-lula-absurdamente-brando-commorales-revela-wikileaks-923390234.asp.

38 Cfr. García Ballesteros, Juan, "La influencia de Venezuela en América Latina", reproducido en el sitio de Rebelión, http: / / www.rebelion.org/noticias/2007/1/45240.pdf, y en Noticias Bolivarianas, del 22 de enero de 2007.

39 Véase Infodefensa.com, 1o. de agosto de 2008 y 11 de septiembre de 2009. 


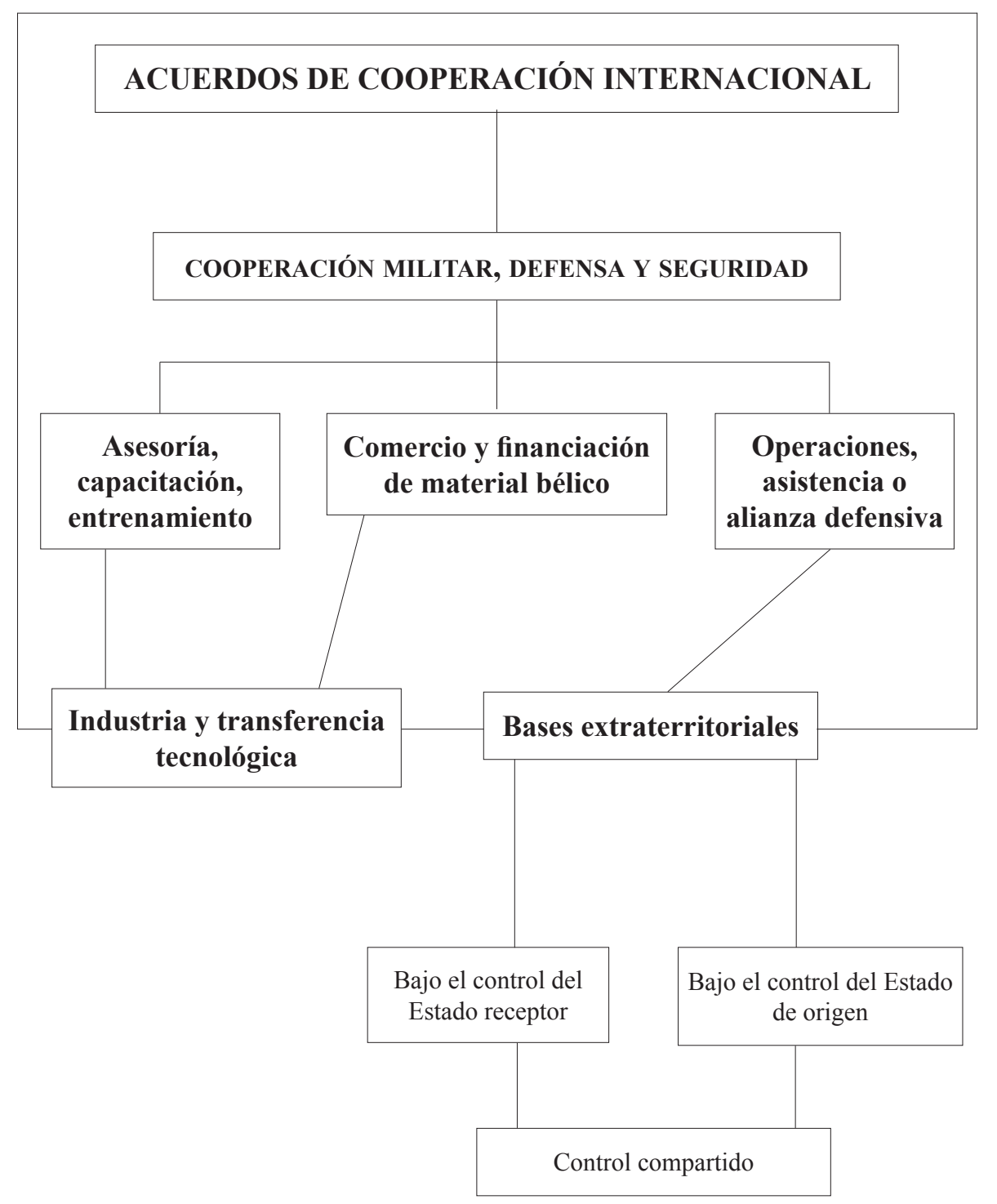

(C) Prof.Dr. Rafael A. Prieto Sanjuán.

2. Implantación y utilización extraterritorial de bases militares

Recordemos que para que la presencia - aún temporal o fugazde tropas extranjeras en territorio nacional sea lícita en DI se requerirá el acuerdo o el consentimiento del Estado receptor, pero, 
en ocasiones, de manera subsidiaria, el de una organización internacional o el de una coalición, ante la ausencia, incapacidad o rechazo de las autoridades locales, por ejemplo, como ocurre actualmente en Libia, al momento de terminar la revisión de este artículo. Ahora, en razón de su difícil consolidación, la intervención de humanidad o la intervención humanitaria, así como la responsabilidad de proteger, ${ }^{40}$ al igual que la legítima defensa preventiva o anticipada, ${ }^{41}$

40 Para ser breves, simplemente notaremos que la "intervención de humanidad" se refiere a una cierta práctica estatal para la protección o liberación de nacionales de un determinado Estado, quienes se encontrarían cautivos o en peligro inminente en territorio extranjero y cuyo gobierno no posee la capacidad o la voluntad de rescatar. Véase entre otros, Rougier, Antoine, "La théorie de l'intervention d'humanité", Revue Générale de Droit International Public, t. 17, 1910, pp. 468-526, Ronzitti, Natalino, Rescuing nationals abroad through military coercion and intervention on grounds of humanity, Dordrecht (Países Bajos), Boston, M. Nijhoff Publishers, Kluwer Academic Publishers, 1985. Por su su parte, la "injerencia o intervención humanitaria”, constituye la promoción de un cierto derecho a intervenir por razones humanitarias, incluso, en detrimento de la voluntad de los Estados intervenidos. Como ejemplo, se piensa en las operaciones "Provide Comfort" en Irak, "Restore Hope" en Somalia, en la antigua Yugoslavia o en el Kosovo. Véase Sandoz, Yves, "Derecho o deber de injerencia, derecho de asistencia: ¿de qué hablamos?”, Revista Internacional de la Cruz Roja, núm. 111, 1992, pp. 231 244; Weil, Carola, "The Protection-Neutrality Dilemma in Humanitarian Emergencies: Why the Need for Military Intervention?”, International Migration Review, vol. 35, 2001, pp. 79-116; Sánchez Rubio, David, "Intervención humanitaria, intervención de humanidad y asistencia: (im)precisiones terminológicas en la (des)protección de derechos humanos”, Revista de Estudios Fronterizos, núm. 3, 2005, pp. 369-392. En fin, una versión más elaborada de lo anterior tiende a consolidarse bajo el nombre de la "responsabilidad de proteger", buscando un equilibrio entre la soberanía de la cual se reclama los Estados y las obligaciones de estos en relación con su población (seguridad humana). Véase, en particular, Evans, Gareth y Sahnoun, Mohamed (copresidentes), La responsabilidad de proteger. Informe de Comisión Internacional sobre Intervención y Soberanía de los Estados (CIISE), Ottawa, International Development Research Centre, 2001, García Pérez, Rafael, “La 'responsabilidad de proteger': un nuevo papel para Naciones Unidas en la gestión de la seguridad internacional”, Revista Electrónica de Estudios Internacionales, núm. 11, 2006, http://www.reei.org/reei\%2011/R.GarciaPerez(reei11).pdf; Revilla Montoya, Pablo C., "Hacia la responsabilidad de proteger. Bases jurídicas para una respuesta colectiva ante crisis humanitarias", Anuario Mexicano de Derecho Internacional, vol. VII, 2007, pp. 643-673.

${ }_{41}$ Entre la doctrina más reciente citaremos solamente a: Louka, Elli, "Precautionary Selfdefense and the Future of Preemption in International Law", Mahnoush Arsanjani et al. (ed.), Looking to the Future: Essays on International Law in Honor of W. Michael Reisman, Leiden [etc.], Nijhoff, 2010, pp. 951-987; Vallarta Marrón, José Luis, "El derecho inmanente a la legítima defensa individual o colectiva en caso de ataque armado: ¿se justifica una interpretación extensiva para incluir medidas preventivas y punitivas?: una visión israelí”, Anuario Mexicano de Derecho Internacional, vol. IX, 2009, pp. 69-115, Kühn, Michael, Unilaterale präventive Ge- 
son fenómenos y doctrinas que no discutiremos en esta oportunidad. ${ }^{42}$

Lo que nos interesa por el instante, es seleccionar algunos casos con el objeto de ilustrar dos situaciones que hay que distinguir de la manera más clara posible. Por un lado, la implantación o instalación de bases militares de un Estado en el territorio de otro y, por otro lado, la utilización de las bases de este último (Estado B) por agentes o miembros de las fuerzas armadas del primero (Estado A) sobre la base de un acuerdo de cooperación militar o estratégica.

\section{A. Instalación de bases militares de un Estado en el territorio de otro}

Las bases militares es el nombre comúnmente acordado a los sitios o emplazamientos que le permiten a las fuerzas armadas (terrestres, aéreas y/o navales) de un Estado estacionarse o acantonarse en un espacio delimitado para almacenar material de guerra, entrenarse, planificar y/o lanzar operaciones de naturaleza militar. ${ }^{43}$ Estas bases, guarniciones, fuertes, cuarteles, batallones, campos de maniobras, o como quiera denominárseles, no suelen presentar mayor inconveniente cuando han sido instaladas en territorio nacional. ${ }^{44}$ Pero, cuando son implantadas

waltanwendung: eine Untersuchung zur "präventiven Selbstverteidigung“ im Völkerrecht, Frankfurt am Main, Lang, 2009, Guiora, Amos N., "Anticipatory Self-Defence and International Law: a ReEvaluation”, Journal of Conflict and Security Law, vol. 13, 2008, núm. 1, pp. 3-24, Shah, Niaz A., "Self-Defence, Anticipatory Self-Defence and Pre-emption: International Law's Response to Terrorism”, Journal of Conflict and Security Law, vol. 12, 2007, núm. 1, pp. 95-126.

42 Cfr. Prieto Sanjuán, Rafael A., “Operación 'Jaque' y 'cerco humanitario': ¿un modelo para el rescate de rehenes en operaciones de seguridad y estabilización?”, en Álvarez L., Luis Fernando et al. (eds.), El derecho internacional —entre lo jurídico y lo político-. Homenaje al Profesor Rafael Nieto Navia, Bogotá, Pontificia Universidad Javeriana-Grupo Editorial Ibáñez, 2010, pp. 311-327.

43 Véase las diferentes acepciones empleadas por el gobierno de los Estados Unidos, Department of Defense Dictionary of Military and Associated Terms, Joint Publication 1-02, Washington, DC, septiembre 2010.

${ }^{44}$ Caso muy especial es el del Peñón de Gibraltar, territorio dependiente del Reino Unido y concebido por Londres como Territorio Británico de Ultramar, donde se encuentra una base aeronaval. Pero, por su estratégica posición (estrecho que comunica el mar Mediterráneo con el océano Atlántico) este territorio aún es objeto de reivindicación por Madrid; tanto más si tenemos en cuenta que el mismo se encuentra en la lista de territorios no autónomos de las Naciones Unidas. Véase en general, González García, Inmaculada y del Valle Gálvez, 
en territorio extranjero, pueden ser objeto de críticas, normalmente provenientes de algunos sectores de la población en cuyo territorio han sido ubicadas. ${ }^{45}$

De manera menos frecuente, pero también factible, es que las críticas provengan de algunos sectores del país de origen (de donde fueron enviadas las tropas), los cuales podrían cuestionar por ejemplo el esfuerzo presupuestal y militar realizado por su propio Estado en territorio extranjero o por una causa ajena. ${ }^{46}$ Más raro aún, pero no imposible, es que terceros (sociedad civil o gobiernos) manifiesten su inconformidad o la amenaza que pueda representar la utilización del territorio de otro Estado — generalmente vecino- por una potencia extranjera. ${ }^{47}$ Aunque no es nuestro objetivo analizar dichas discrepancias, algunos ejemplos nos mostrarán mejor este fenómeno de extraterritorialidad.

La situación de mayor actualidad — aunque tristemente célebre por la violación de derechos humanos - seguramente sea la de la Base Naval de los Estados Unidos en Guantánamo, ${ }^{48}$ como resultado del Tratado

José Alejandro (coords.), Gibraltar y el Foro Tripartito de Diálogo, Madrid, Dykinson, 2009 y, en especial, Liberal Fernández, Ángel, “Gibraltar, base militar”, pp. 255-273.

45 Véase por ejemplo las manifestaciones en Okinawa, Japón, demandando el cierre de la base militar estadounidense Futenma. BBC, 25 de abril de 2010.

46 Manifestaciones de este tipo se han registrado en Estados Unidos, Gran Bretaña, Países Bajos o Alemania, en razón de su participación en Afganistán, por ejemplo. Cfr. "Muertes de tropas extranjeras en Afganistán se acercan a 600 en 2010”, Americaeconomia, 24 de octubre de 2010, http: / / www.americaeconomia.com / politica-sociedad/mundo / muertes-de-tropas-extranjeras-enafganistan-se-acercan-600-en-201o; Batty, David, "Thousands protest against Afghanistan war, Military families lead anti-war protest in London as Nato leaders agree exit strategy", The Guardian, 20 de noviembre de 2010, http://www.guardian.co.uk/uk/2010/nov/20/protesters-mar ch-against-afghanistan-war-london.

47 Véase la manera vehemente con la que el gobierno de Caracas rechazó el acuerdo celebrado entre Washington y Bogotá, al punto de retirar su embajador en Bogotá, como medida adicional a la cesación de pagos y al embargo comercial que ya venía aplicando sobre los productos en proveniencia de Colombia. "Chávez insiste en cuestionar las bases militares de Colombia”, ABC, 31 de agosto de 2009, http://www.abc.es/20090831/internacional-iberoamerica/chavez-insiste-cuestionar-bases-200908310037.html, y "Chávez denuncia que desde bases militares en Colombia se planifican ataques contra Venezuela", TeleSur, 13 de noviembre de 2009, http://www.telesurtv.net/noticias/secciones/nota/61692-NN/chavez-denuncia-que-desdebases-militares-en-colombia-se-planifican-ataques-contra-venezuela.

48 También conocida como Guantanamo Bay Naval Base o GITMO. Cfr. entre otros, Andrés, Gabriel E., et al. (coords.), Guantánamo y el Imperio del Derecho, Universidad Católica de Córdoba, Argentina, Pontificia Universidad Javeriana, Bogotá, 2010. Situación similar, y no 
cubano-estadounidense de 1903 concerniente al arrendamiento perpetuo de dicho emplazamiento, ${ }^{49}$ aunque La Habana considere el tratado como nulo y califique a Washington de fuerza ocupante, ${ }^{50}$ el hecho es que allí funciona la estación naval conocida como Fuerza de Tarea Conjunta (Joint Task Force) de Guantánamo, donde los Estados Unidos ejercen "complete jurisdiction and control over and within said areas". ${ }^{51}$ Dicho de otra manera, a pesar de encontrarse fuera del territorio de los Estados Unidos, existe una competencia de estos en función de la prestación del servicio público de defensa nacional; atribuida o reconocida por el derecho internacional. ${ }^{52}$ La otra Fuerza de Tarea Conjunta (JTF, por su sigla en inglés), llamada Bravo, se encuentra situada en la Base Aérea Soto Cano en Palmerola, Honduras, desde agosto de 1984, la cual fue creada para ejercer comando y control de las fuerzas militares estadounidenses y para realizar ejercicios en la República de Honduras, incluidos ejercicios de ínter agencia en el Área de Operaciones Conjunta (JOA, por su sigla en inglés), para brindar seguridad y cooperación regional. ${ }^{53}$

menos preocupante, es la de la Isla (atolón) Diego García, en el Archipiélago Chagos, territorio británico en el Océano Índico, cuya población fue expulsada en 1966, para ser alquilada a los Estados Unidos, donde también funciona una base y una prisión secreta, en la cual se detendrían y procesarían sospechosos de terrorismo, para ser posteriormente enviados a Guantánamo. Véase Sand, Peter H., “Diego Garcia: nouveau 'trou noir' dans l'océan Indien?”, Revue Générale de Droit International Public, t. 113, 2009, núm. 2, pp. 365-374 y, Vine, David, Island of shame: the secret history of the U.S. military base on Diego Garcia, Princeton, NJ, Princeton University Press, 2009

49 Artículo I del tratado. Véase texto en http://avalon.law.yale.edu/20th_century/dip_cuba 002.asp.

50 Cfr. Castro, Fidel, Guantanamo: why the illegal base must be returned to Cuba, Nueva York, Ocean Press, 2010.

51 Ibidem, artículo III.

52 A ese título resulta particularmente ilustrativo el laudo arbitral conocido como Desertores de Casablanca (Francia c. Alemania), decidido el 22 de mayo de 1909.

53 Véase información en la página del Comando Sur del del Departamento de Defensa los Estados Unidos, http://www.jtfb.southcom.mil/enespanol/index.asp. También se recordarán las otrora bases norteamericanas en Panamá: Howard, Koobe y Rodman, sobre el litoral Pacífico y, el Fuerte Sherman, en el Caribe, o en Puerto Rico, la Estación naval de Roosevelt Roads y las áreas de práctica para bombardeo y maniobras en las islas de Vieques (Polígono Interno) y de Culebra. 
Sin embargo, los Estados Unidos no son los únicos en contar con bases en territorio extranjero. En tiempos de la Guerra Fría, la Unión Soviética también utilizó con fines estratégicos el territorio de aquellos países bajo su esfera de influencia. Ni más ni menos, basta recordar la denominada crisis de los misiles, cuyo dispositivo de lanzamiento fue instalado por Moscú en Sagua La Grande (Cuba) en 1962, provocando una situación que los observadores no dudan en calificar como la más cercana a una guerra nuclear. ${ }^{54}$ De igual forma, los proyectos de implantar bases rusas en las caucásicas repúblicas rebeldes de Abjasia y Osetia del Sur, ambas en Georgia, ${ }^{55}$ así como en Venezuela, ${ }^{56}$ no dejan de sugerir una especie de renacimiento de la era bipolar, cuyo escenario se extendería hasta el Asia Central y Latinoamérica. ${ }^{57}$

En definitiva, sería errado desconocer que el poderío militar, así como su despliegue extraterritorial, continúa siendo un factor de potencia estatal de primer orden. Incluso, Estados como Francia, que tien-

\begin{abstract}
${ }^{54}$ Cfr. Kennedy, Robert F., Thirteen Days: A Memoir of the Cuban Missile Crisis, New York, Norton, 1969; Allison, Graham y Philip Zelikow, Essence of Decision: Explaining the Cuban Missile Crisis, 2a ed., Longman, New York, 1999 (1a. ed. 1971); Allyn, Bruce J. et al. (eds.) Back to the Brink: proceedings of the Moscow Conference on the Cuban Missile Crisis, January 27-28, 1989, Cambridge, MA, Center for Science and International Affairs, Harvard University, 1992; Touzé, Vincent, Cuba, 1962. La Crise des missiles, Mémorial de Caen, Caen, 2000, y Scott, Len, The Cuban Missile Crisis and the Threat of Nuclear War: Lessons from History, Londres, Continuum, 2007.
\end{abstract}

55 "Rusia anuncia que ya cuenta con bases militares en Abjasia y Osetia del Sur", El Espectador, 19 de noviembre de 2008, http: / /www.elespectador.com/print/91606; "Rusia instaló misiles antiaéreos en Abjasia y Osetia del Sur”, El Tribuno, 12 de agosto de 2010, http: / / www.eltribuno.info/salta / diario/2010/08/12/internacional / rusia-instalo-misiles-antiaereos-enabjasia-y-osetia-del-sur.

56 No obstante, en el caso de Venezuela, pareciera tratarse más de especulaciones originadas en la eufórica respuesta del presidente Chávez a la cooperación con Rusia. Cable originado por la agencia rusa Interfax y reproducido por un gran número de medios de comunicación (Reuters, DPA, El Mundo, Clarín, El Universal, Diario El Nacional, etcétera) del 22 de julio de 2008.

57 Desde luego, una vez terminada la confrontación ideológica, resulta curioso observar cómo las dos antiguas superpotencias de la Guerra Fría procuran aprovechar los espacios políticos que les permitan un reposicionamiento estratégico; el caso más llamativo, es el que les procura la ex República soviética de Kirguistán, donde cada una de ellas (EU/Rus.) dispone de su propia base militar. Cfr. Lachowski, Zdzislaw, Foreign military bases in Eurasia, SIPRI Policy Paper no. 18, Estocolmo, Stockholm International Peace Research Institute, 2007, http: / / books.sipri.org/files/PP/SIPRIPP18.pdf. 
den a ubicarse en medio de los dos extremos, cuenta con una importante presencia orbital, tanto marítima como terrestre, por medio de sus denominadas "fuerzas preposicionadas" (bases militares permanentes) en territorio de ultramar, tanto galo, ${ }^{58}$ como extranjero, a saber Gabón, Yibutí y Senegal $;^{59}$ a lo que se suma la primera base militar abierta después de su era colonial, en los Emiratos Árabes Unidos. ${ }^{60}$ Tampoco podía faltar el Reino Unido, ciertamente más alineado a los intereses norteamericanos, pero también rico de un pasado colonial, el cual le ha permitido, por ejemplo, seguir presente en Chipre con dos Bases Aéreas Soberanas (SBA, por su sigla en inglés), disponer de un Equipo de Apoyo de Paz Británico (BPST) y una Unidad de Entrenamiento del Ejército (BATUK) en Kenia, un Equipo de Entrenamiento a la Asistencia Militar Internacional (IMATT) en Sierra Leona, mientras que en Brunei posee un Batallón de Infantería y el vuelo de un Helicóptero Bell 212 de los Cuerpos del Ejército del Aire y, en Belice, otra Unidad de Entrenamiento de Apoyo del Ejército (BATSUB), así como en Suffield, Canadá (BATUS). ${ }^{61}$

No obstante, también es necesario constatar que, en detrimento de una presencia regular de fuerzas armadas por fuera del territorio nacional, el caso de las bases militares extranjeras no es un fenómeno que se reproduzca tan fácilmente, al menos no, como tradicionalmente se había concebido. A nuestro juicio, tres situaciones particulares han motivado dicha situación y, en cambio, han hecho que aumente la cooperación bilateral y multilateral en diversas aéreas de la defensa y seguridad. Ante todo, la opinión acerca de las bases militares - especialmente la del Estado concernido- no suele ser la más positiva, en el sentido de su representación bélica en el imaginario colectivo. Así, una base extranjera podría no ser vista como un instrumento defensivo,

58 Hacemos referencia a las entidades franceses de ultramar de Martinica y Guadalupe, en las Antillas, así como a la Guyana, Isla Reunión, Mayotte (del archipiélago de Comores), Nueva Caledonia, Polinesia francesa y, en general, a su presencia marítima, especialmente en los Océanos Pacífico e Índico.

59 Véase Ministerio de Defensa: http: / / www. defense.gouv.fr/ema/forces-prepositionnees.

${ }^{60}$ Implantation militaire française aux Émirats arabes unis (IMFEAU). Idem.

${ }^{61}$ Lo anterior, sin contar con las bases en sus territorios de ultramar, el peñón de Gibraltar y las Islas Malvinas (Falkland, para los británicos). Véase http://www.army.mod.uk/operationsdeployments/overseas-deployments/default.aspx. 
sino como una amenaza para el mismo país de acogida o para un tercero. Enseguida, la implantación y mantenimiento de una base militar en el extranjero implica tanto un costo político, como militar y económico de no poca monta para el Estado de origen. En fin, está demostrado que la complejidad de las amenazas a la paz y seguridad internacionales no se limitan al aspecto militar, lo que demanda acciones igualmente complejas y conjuntas de los países afectados. Es por lo anterior que, en la época actual, pensaríamos que existe mayor interés en utilizar las áreas militares del Estado receptor que la instalación de bases extranjeras en su territorio.

\section{B. Utilización de bases militares de un Estado} por las fuerzas armadas de otro

En esta hipótesis ya no se trata de la utilización exclusiva de una porción del territorio nacional por una potencia extranjera, sino de la locación o la participación conjunta en un ejercicio de defensa y seguridad. Como ejemplos de esta situación tenemos en otra parte del Caribe, en la Antillas Holandesas, el denominado Lugar de Operaciones de Avanzada (FOL, por su sigla en inglés) ${ }^{62}$ de Aruba-Curazao, a cargo del Comando Sur (Southcom Forward Operating Location) de los Estados Unidos. De acuerdo con Washington, no se trata de bases como tal, sino del préstamo o alquiler de campos aéreos ya existentes, cuyo propósito oficial es el de apoyar misiones antidrogas de manera rápida y efectiva ${ }^{63}$ Así, estas locaciones se encuentran ubicadas en los aeropuertos internacionales Hato de Curazao y Reina Beatriz de Aruba, gracias a un acuerdo suscrito con el Reino de los Países Bajos en marzo de 2000; teniendo presente que dichas FOL permiten a las aeronaves de los países aliados de Estados Unidos en la región (Estados Unidos, Países Bajos, Reino Unido, Canadá y Francia) el uso de sus instalaciones para la lucha contra el tráfico ilícito de drogas. ${ }^{64}$

62 Según el Comando Sur del Departamento de Defensa los Estados Unidos las Forward Operating Locations consisten en locaciones ubicadas mediante acuerdo en el territorio de otro país, desde donde se puede extender comando y control o proveer apoyo a entrenamiento y operaciones tácticas, http: / / www.southcom. mil/AppsSC/factFiles.php?id=63.

63 Idem.

${ }^{64}$ Así: "[w]ith the closure of Howard Air Force Base in Panama in 1997, the establishment of FOLs within what officials call "source zones" (Andean Ridge) and "transit zones" (Ca- 
La otra FOL se encuentra en el aeropuerto internacional de Comalapa, en El Salvador, cuyo principal objetivo es el de controlar los corredores centroamericanos de contrabando hacia el Pacífico oriental. ${ }^{65}$ Se completa así, el control norteamericano sobre América Central y el Caribe, quedando parcialmente por fuera el de Sudamérica, en razón de la no renovación en septiembre de 2009 por parte de Quito del acuerdo que permitía a Washington la utilización de la FOL de Manta en Ecuador, más precisamente de la base aérea ecuatoriana Eloy Alfaro, con la misión de detener el tráfico ilegal de droga a lo largo del Océano Pacífico. ${ }^{66} \mathrm{Si}$ bien es cierto que parte del equipo utilizado para misiones de vigilancia contra las drogas fue reubicado en Comalapa y Curazao, la polémica generada por la opción de hacerlo en Colombia o en Panamá, es precisamente la que originó la redacción de este artículo.

En efecto, recordemos que en el último trimestre de 2009, Colombia y Estados Unidos firmaron un acuerdo que permitiría el uso de las instalaciones de las bases aéreas de Palanquero, Malambo y Apíay, así como las Bases Navales de Cartagena y Bahía Málaga y, en fin, los Fuertes Militares de Tolemaida y Larandia. ${ }^{67}$ Pero, en agosto de 2010, la Corte Constitucional de Colombia declaró inexequible el Acuerdo por vicios de procedimiento, quedando pendiente de presentación ante el Congreso de la República. ${ }^{68}$ Respecto de Panamá, es importante notar que la invasión que tuvo lugar para capturar a Manuel Noriega, ex

ribbean, Eastern Pacific and Central America), was critical to the U.S. ability to implement the National Drug Control Strategy. The agreed upon locations allow U.S. and allied nation interdiction aircraft to be forward deployed closer to cocaine departure points in the source zone. The operations out of the FOLs now yield more counter-drug surveillance "coverage" — at less cost — than previous efforts out of Howard Air Force Base. Idem.

65 Idem.

66 Idem.

${ }^{67}$ Acuerdo complementario para la cooperación y asistencia técnica en defensa y seguridad entre los gobiernos de la República de Colombia y de los Estados Unidos de América”, suscrito en Bogotá el 30 de octubre de 2009. Véase http://web.presidencia.gov.co/sp/2009/noviembre/03/acuerdo.pdf.

68 De acuerdo con las demandas interpuestas contra dicho Acuerdo, se omitió el trámite de discusión y aprobación por el Congreso y, por ende, el control automático u oficioso de la Corte Constitucional. En consecuencia, ésta, ordena remitirlo al presidente de la República "para que le imparta el trámite constitucionalmente previsto para los tratados internacionales". Y, declara, que dicho Acuerdo "no puede surtir efectos en el ordenamiento interno colombiano hasta tanto cumpla con el trámite constitucional previsto para los tratados en forma solemne, de conformidad con lo establecido en los artículos 150.16, 154, 157, 158, 160, 
comandante en jefe de las Fuerzas de Defensa, con el soporte de bases militares estadounidenses implantadas en las riveras del Canal de Panamá, en 1989, parece estar aún fresco en la memoria de un sector de la población. De tal suerte, la protesta social no se ha hecho esperar y, evidentemente, ha dificultado que las autoridades panameñas den su aprobación para un nuevo acuerdo. ${ }^{69}$

Así las cosas, lo que en el fondo algunos temen es que la celebración de acuerdos que implican la utilización de ciertos sitios o instalaciones nacionales por fuerzas extranjeras no correspondan en la práctica a los objetivos formalmente pactados. Es decir, si dichas locaciones van a ser utilizadas de otra forma o, si lo que se suponía un acuerdo de cooperación, no podría ser otra cosa que una base militar bajo el dominio exclusivo de una potencia extranjera. Es precisamente esta inquietud la que expresara con vehemencia el gobierno de Caracas frente al acuerdo de su homólogo de Bogotá con Washington, en el sentido de que las "bases militares gringas" constituirían la punta de lanza para una eventual invasión contra Venezuela u otros países de la región. ${ }^{70}$

Sin embargo, de manera curiosa, es la misma preocupación que se manifestara en Bolivia frente a la construcción de un puerto fluvial en la localidad de "Puerto Guijarro" y de un Fuerte militar en el noreste del país, en Riberalta, departamento de Beni (zona amazónica), prevista en el Convenio de Cooperación e Intercambio de Visiones Estratégicas en Materia de Defensa suscrito por los respectivos mandatarios en mayo de 2006. ${ }^{71}$ Por otro lado, Paraguay también había planteado su inquietud por las informaciones relativas a la instalación de una base militar boliviana a 200 kilómetros de su frontera, la cual contaría también con financiación venezolana, ${ }^{72}$ así como la contribución de Caracas al esta-

165, 224 y 241 numeral 10 de la Carta Política”. Véase Corte Constitucional, Auto 288/10 del 17 de agosto de 2010. Ref.: expedientes (acumulados) D-7964 y D-7965.

${ }_{69}$ Púlsar, agencia informativa, "Movilización rechaza la instalación de bases de EE. UU. en Panamá”, 3 de noviembre de 2010 http: / / www.agenciapulsar.org/nota.php?id=16123.

70 Supra, nota 40.

71 Artículo 6 del Acuerdo Complementario al Convenio Básico de Cooperación Técnica entre la República de Bolivia y la República Bolivariana deVenezuela. Disponible en Gaceta Oficial (Venezuela) No. 38.684 del 16 de mayo de 2007, http://www.tsj.gov.ve/gaceta/mayo/160507/16050738684-01.html y supra, nota 32.

72 "Nicanor pedirá a Chávez no generar discordia en la región”, $A B C, 18$ de septiembre de 2006, http: / / archivo.abc.com.py/2006-09-18/articulos/279571/nicanor-pedira-a-chavez-nogenerar-discordia-en-la-region. 
blecimiento del Comando Militar (regional) del Plata, con asiento en la ciudad de San Ignacio de Velasco, en el departamento de Santa Cruz, y cuyas unidades orgánicas se encuentran desplegadas en su mayoría a lo largo de la frontera chaqueña. ${ }^{73}$

¿Pero, en concreto, cuál es la interpretación jurídica que podríamos realizar respecto de la discusión estratégica? Ciertamente, es comprensible que terceros (gobiernos y sociedad civil) puedan albergar temores frente a la posibilidad de que un Estado de acogida de tropas extranjeras desborde los parámetros convencionales, generales y especiales, del respectivo acuerdo, pero carecen del derecho de intervenir en asuntos que son de la competencia exclusiva de los Estados concernidos. Más bien, con base en la publicidad de los tratados, los actores externos podrán estar atentos a que los términos de aquellos no sean violatorios de otros tratados, de la costumbre internacional o de normas imperativas, caso en el cual, el nuevo tratado adolecería de nulidad y vincularía la responsabilidad internacional de quien lo celebre, contraviniendo normas preexistentes o de mayor rango.

En ese orden de ideas, lo más interesante para el jurista será analizar las consecuencias que podrían resultar de una eventual acción extraterritorial, así como la imputación de los actos que podrían llegar a tener el calificativo de agresión, lo que estudiaremos en nuestra segunda parte.

\section{ATRIBUCIÓN DE HECHOS QUE PODRÍAN CONSTITUIR UN ACTO DE AGRESIÓN: LA CUESTIÓN DEL CONTROL}

A partir del supuesto de envío, tránsito o recepción de tropas de un Estado en el territorio de otro, así como el de eventuales actos de agresión, la cuestión más espinosa que habría que responder es la concer-

73 "Una irresponsabilidad de Lugo podría perjudicar muy gravemente al Paraguay", idem, 3 de octubre de 2009, http://www.abc.com.py/nota/30969-una-irresponsabilidad-de-lugo-podriaperjudicar-muy-gravemente-al-paraguay, y "Evo tiene 8 bases y 9000 soldados frente al Chaco", idem, 27 de marzo de 2010, http: / / www.abc.com.py/nota/95114-evo-tiene-8-bases-y-9-000-soldados-frente-al-chaco. 
niente a la atribución del hecho ilícito en caso de agresión contra un tercer Estado. Teóricamente, la cuestión no resulta difícil de responder; siguiendo la práctica internacional, la cual ha sido codificada y retomada por la jurisprudencia internacional, en términos generales:

[h]ay hecho internacionalmente ilícito del Estado cuando un comportamiento consistente en una acción u omisión:

a) Es atribuible al Estado según el derecho internacional; y

b) Constituye una violación de una obligación internacional del Estado. ${ }^{74}$

Ahora bien, dado que el elemento material resultaría bastante evidente en caso de agresión, ${ }^{75}$ nos parece que lo más aconsejable es dedicar las líneas siguientes al elemento subjetivo, es decir, la atribución de aquellos hechos al Estado que envía sus tropas en territorio extranjero (A), así como a la eventual responsabilidad del Estado receptor (B).

74 Artículo 2 del Proyecto sobre la Responsabilidad del Estado por hechos internacionalmente ilícitos, adoptado por la Comisión de Derecho Internacional (CDI) en su 53o. periodo de sesiones (A/56/10) y anexado en la Resolución 56/83 de la Asamblea General de las Naciones Unidas, el 12 de diciembre de 2001. Antes citado, supra, nota 1 y, en adelante, PREHII, o simplemente, el Proyecto sobre responsabilidad.

75 Además de las hipótesis $f$ y $g$, que veremos en la siguiente sección (II:B), se encuentra: “a) La invasión o el ataque por las fuerzas armadas de un Estado del territorio de otro Estado, o toda ocupación militar, aún temporal, que resulte de dicha invasión o ataque, o toda anexión, mediante el uso de la fuerza, del territorio de otro Estado o de parte de él; b) El bombardeo, por las fuerzas armadas de un Estado, del territorio de otro Estado, o el empleo de cualesquiera armas por un Estado contra el territorio de otro Estado; c) El bloqueo de los puertos o de las costas de un Estado por las fuerzas armadas de otro Estado; d) El ataque por las fuerzas armadas de un Estado contra las fuerzas armadas terrestres, navales o aéreas de otro Estado, o contra su flota mercante o aérea; e) La utilización de fuerzas armadas de un Estado, que se encuentran en el territorio de otro Estado con el acuerdo del Estado receptor, en violación de las condiciones establecidas en el acuerdo o toda prolongación de su presencia en dicho territorio después de terminado el acuerdo". Artículo 3o. del Anexo a la Resolución 3314 de la XXXIV Asamblea General de las Naciones Unidas, adoptada con ocasión de su 2319a. sesión plenaria, el 14 de diciembre de 1974; retomada por la definición recientemente adoptada por la Asamblea de Estados parte del Estatuto de la CPI. Resolución sobre el crimen de agresión del 11 de junio de 2010, aprobada por consenso en la decimotercera sesión plenaria de la Conferencia de revisión del estatuto de la CPI. Doc. RC/Res.6, versión avanzada del 28 de junio de 2010 . 
La regla general nos indica que al Estado de envío (el Estado A en nuestro ejemplo) se le atribuirán los actos de sus agentes o miembros de las fuerzas armadas o de policía, al igual que el ejercicio de una competencia extraterritorial sobre otro Estado, bien sea de manera temporal, regular o permanente. Así pues, sobre la base convencional o por acuerdo en forma simplificada - queda excluido el caso de ocupación, pues estaríamos haciendo alusión a una agresión contra el Estado receptor $^{76}$ - el Estado de origen, e incluso los líderes políticos y militares (como quedó demostrado en la Conferencia de revisión de Kampala) quienes dispondrían de agentes en el Estado B, podrían comprometer directamente su responsabilidad si desde allí agreden a otro Estado, así se encuentren simplemente de tránsito (1) o estacionados de forma más o menos continua (2).

\section{A. Tránsito de tropas extranjeras en territorio ajeno a su soberanía}

El primer caso que expondremos, en orden de menor a mayor intensidad, es el del tránsito, paso o presencia temporal de agentes de un determinado Estado, el Estado A, en el territorio de otro Estado, el Estado B, o incluso, en un espacio internacional (por ejemplo en alta mar). No obstante, en este último evento, al no existir controversia interestatal sobre la apropiación de dicho espacio, por lo general, el hecho ilícito se limitará al elemento material y, no tanto, al problema de imputación o atribución que nos ocupa en este trabajo.

La hipótesis de una presencia pasajera de tropas extranjeras, la encontramos cuando las fuerzas pertenecientes a un determinado Estado utilizan el territorio de otro como parte de su itinerario, terrestre, marítimo o aéreo, para abastecerse, proceder a ejercicios o maniobras militares, o incluso, para preparar y lanzar desde el territorio de tránsito, una incursión armada contra un tercer Estado. Ejemplos de esta situación los tenemos desde la época de la Conquista y las guerras de

${ }^{76}$ Literales a y e, especialmente, lo que implicaría que el Estado A aprovechase su presencia en el Estado B para agredirlo. 
Independencia, cuando las fuerzas enviadas por la metrópoli debían transitar por territorios ajenos a su soberanía o posesión, con el objetivo de contrarrestar la insurrección armada en sus colonias. ${ }^{77}$ Asimismo, en la Segunda Guerra Mundial, cuando tropas de las potencias aliadas transitaban por toda Europa, ingresando por el Mar del Norte o por el Mediterráneo, procurando la derrota de Alemania. ${ }^{78}$

Ahora, si bien es cier to que el paso de tropas se ha hecho especialmente evidente en tiempos de guerra clásica, generalmente entre potencias estatales distantes unas de otras, dicho tránsito también tuvo lugar con ocasión de luchas contrainsurgentes durante el periodo de coexistencia entre las dos superpotencias; sin embargo, no será sino hasta finales de la Guerra Fría, cuando retomará vigencia la discusión sobre la cuestión. Así, por ejemplo, con la coalición que se organiza en 1991 para expulsar las tropas invasoras de Irak en territorio kuwaití; varios países, incluso de la Liga Árabe, participaron en la coalición, ${ }^{79}$ y Arabia Saudí, en especial, permitió que fuera utilizado su territorio (base aérea de Dhahran) para lanzar desde allí la campaña de liberación. ${ }^{80}$ Ocho años después, sería el caso de los recién admitidos miembros de la OTAN, en su campaña aérea contra la República Federal de Yugoslavia y Montenegro en 1999, mejor conocida como la guerra de Kosovo. En efecto, recordaremos cómo varios aviones de combate de la alianza defensiva se alistaban y partían desde la base aérea de Taszar en Hungría. ${ }^{81}$

Haciendo abstracción del carácter lícito o no de las mencionadas acciones, lo que necesitamos determinar es a quién se le atribuiría este

77 Véase caso relativo al Derecho de paso por territorio de la India (Portugal c. India), CIJ, fallo del 12 de abril de 1960.

78 Veáse la rúbrica cronológica en diferentes portales especializados de la Red: http:// www.seconde-guerre.com; http: / / www.secondworldwar.co.uk, y http: / /www.worldwar-2.net.

79 Véase Infografía en http://static.elespectador.com/archivos/2011/01/926057039f1b0e3a 862f13c2ab3ac168.pdf.

80 Cfr. Hutchison, Kevin Don, Operation Desert Shield/Desert Storm: chronology and fact book, Westport, CT [etc.], Greenwood Press, 1995

81 Una información muy completa - incluida bibliografía externa - acerca de la campaña aérea se encuentra disponible en el sitio de la OTAN, http://www.nato.int/cps/en/natolive/ topics_49602.htm?. Cfr. especialmente, Hendrickson, Ryan C., "NATO’s Visegrad Allies: The First Test in Kosovo", Journal of Slavic Military Studies, vol. 13, núm. 2, 2000, pp. 25-38, y Lachowski, Zdzislaw, Foreign military bases in Eurasia, cit. 
tipo de comportamiento, es decir, si la eventual violación de una obligación internacional es atribuible al Estado A, que utilizó la fuerza, o al Estado B, que permitió que el primero utilizara su territorio para llevar a cabo una acción coercitiva. Veamos, el artículo 4.1 del Proyecto de la Comisión de Derecho Internacional (CDI) sobre la Responsabilidad del Estado por Hechos Internacionalmente Ilícitos establece que "[s]e considerará hecho del Estado según el derecho internacional el comportamiento de todo órgano del Estado, ya sea que ejerza funciones legislativas, ejecutivas, judiciales o de otra índole”. ${ }^{82}$ Esto significa que tal uso de la fuerza no sería imputable sino al Estado de envío. Por supuesto, las fuerzas armadas y de policía — normalmente adscritas a la rama del Poder Ejecutivo — constituyen órganos del Estado y, sus miembros, agentes del mismo, habilitándolos para vincular la responsabilidad del Estado.

Recordemos también que, en el ejercicio de su defensa y seguridad, o sobre la base de la cooperación internacional, el Estado puede llegar a ejercer una competencia de carácter extraterritorial, como lo observamos en la primera parte de este ensayo, sobre la base de un acuerdo formal o del consentimiento — menos informal — entre las partes involucradas. Pero, en ciertos casos, dicho ejercicio puede darse además como manifestación de un acto unilateral, por ejemplo con base en la antigua "intervención de humanidad", para el rescate de sus nacionales en territorio extranjero, pasando por la denominada "intervención humanitaria", hasta llegar a la también discutida "responsabilidad de proteger", ${ }^{83}$ últimos dos eventos en los que el vínculo de nacionalidad no cuenta.

Ahora bien, a pesar del debate generado por las situaciones antes enunciadas, la situación más polémica tiene que ver con la presunta aceptación o anuencia del Estado de tránsito de tropas extranjeras. No solamente por la legalidad de dicha presencia, sino por la eventual comisión de hechos ilícitos de dicho personal. En ese caso, ¿a quién se le imputaría ese acto? De acuerdo con el mencionado proyecto, "[s]e considerará hecho del Estado según el derecho internacional el comporta-

82 Supra, nota 70.

83 Supra, nota 38. 
miento de un órgano puesto a su disposición por otro Estado, siempre que ese órgano actúe en el ejercicio de atribuciones del poder público del Estado a cuya disposición se encuentra" (énfasis fuera del texto). ${ }^{84}$

En consecuencia, en el caso en discusión, habrá que determinar al servicio o bajo el control de cuál Estado se encontraban las tropas extranjeras al momento del ilícito. ¿Es que el Estado de origen guardaba el control absoluto sobre sus hombres, o es que eventualmente habría dispuesto que sus elementos militares estuviesen al servicio del Estado receptor? Dudamos mucho que esta última opción sea la regla, pues los Estados suelen prestar apoyo militar a otros, pero muy raras veces colocan sus agentes al servicio de otro Estado y sin conservar control alguno. Otra situación muy diferente es que los Estados contribuyan con contingentes nacionales al esfuerzo de una coalición armada o a una alianza defensiva, como por ejemplo la OTAN, caso en el cual habría que determinar la titularidad de la comandancia, a fin de establecer la respectiva responsabilidad. ${ }^{85}$

Asimismo, inspirándose en el derecho penal, el Proyecto de la CDI considera las hipótesis de una especie de Estado determinador, A (el que dirigiría o controlaría la situación), y la de aquel que coaccionaría a otro, B (el Estado receptor), para cometer un acto de agresión. Estas circunstancias también permitirían establecer a quién atribuir la responsabilidad por los hechos de fuerzas expedicionarias o temporales en territorio extranjero. Adicionalmente, si el Estado de origen de dicho contingente cometiese un hecho ilícito, éste sólo podría eximirse de responsabilidad con base en las circunstancias excluyentes de ilicitud que figuran en el Proyecto sobre Responsabilidad: consentimiento, legítima defensa, contramedidas, fuerza mayor, peligro extremo y estado de necesidad. ${ }^{86}$

En ese orden de ideas, resultaría difícil excluir la responsabilidad del Estado por la comisión de un hecho ilícito como la agresión, resultante

84 Artículo 6o. del PREHII.

85 Sin embargo, el asunto relativo a la Licitud del uso de la fuerza (CIJ, Serbia y Montenegro c. Bélgica et al., ordenanza del 6 de junio de 1999) resulta bastante ilustrativo del hecho que los Estados prefieren demandar a otros Estados antes que a una organización internacional, dada la dificultad de hacer efectiva la responsabilidad de esta última.

86 Capítulo V (artículos 20 a 25) del PREHII. 
del tránsito de sus tropas en territorio extranjero, salvo que el hecho pueda justificarse como respuesta a un primer ilícito contra ellas. Pero, aún en esta eventualidad, no procedería la exclusión de ilicitud cuando la respuesta del Estado A "no esté de conformidad con una obligación que eman[e] de una norma imperativa de derecho internacional general". ${ }^{87}$ En consecuencia, si la prohibición de la agresión constituye una norma de ius cogens, la respuesta de un contingente militar en tierra extranjera no podría ser otra agresión, sino un acto de legítima defensa, o un uso limitado de la fuerza para responder dentro del marco de la legalidad internacional ante un peligro extremo o frente a un estado necesidad, o incluso a título de contramedidas o represalias armadas contra elementos militares — no necesariamente estatales - que habrían lanzado un primer ataque de similar naturaleza. ${ }^{88}$

\section{B. Presencia regular o permanente de tropas extranjeras}

El segundo caso, en orden de intensidad, se refiere ya no a una presencia puntual o fugaz, sino a una una presencia más bien regular o continua, tanto de agentes, material y equipo militar del Estado A en el territorio del Estado B. Como ya vimos, esta situación debería darse normalmente mediante la implementación de un acuerdo de cooperación o de un convenio militar entre los Estados de origen y el receptor, por medio del cual se autoriza la instalación y gestión de una base militar del primero en territorio del segundo. ${ }^{89}$ En cualquier caso, lo determinante en este evento es que el control sobre los elementos militares (personal, bienes y medios) suele conservarlo de manera exclusiva y excluyente el

87 Ibidem, artículo 26.

${ }^{88}$ Véase entre otros, Ruys, Tom y Verhoeven, Sten, "Attacks by Private Actors and the Right of Self-Defence”, Journal of Conflict and Security Law, vol. 10, 2005, núm. 3, pp. 239 320, Wettberg, Gregor, The International Legality of Self-Defense Against Non-State Actors: State Practice from the U. N. Charter to the Present, Lang, 2007; Waisberg, Tatiana, "The ColombiaEcuador Armed Crisis of March 2008: the Practice of Targeted Killing and Incursions Against Non-State Actors Harboured at Terrorist Safe Havens in a Third Party State", Studies in Conflict and Terrorism, vol. 32, núm. 6, 2009, pp. 476-488, y Van Steenberghe, Raphaël, "Self-Defence in Response to Attacks by Non-state Actors in the Light of Recent State Practice: a Step Forward?", Leiden Journal of International Law, vol. 23, núm. 1, 2010, pp. 183-208.

89 Supra, Primera Parte, especialmente la sección A.2 y B.1. 
Estado A, acordándoles un estatus similar al del personal diplomático y consular, así como a sus bienes, muebles e inmuebles, por parte del Estado B.

Nuevamente, en la hipótesis de bases militares en territorio extranjero, difícilmente se podría demostrar que el Estado de envío no disponía del control sobre esta especie de extensión extraterritorial de una de sus funciones públicas esenciales, pero, en un espacio físico sobre el cual el Estado A pretende garantizar parte de su defensa nacional, es decir, a partir del territorio del Estado B, quien acoge u otorga el permiso para instalar allí bases militares del primero.

Ejemplo de lo anterior, lo constituyen las bases norteamericanas implantadas en diversos puntos del planeta ${ }^{90} \mathrm{y}$, en particular, en el "continente latinoamericano”, en Puerto Rico o en Panamá, en el pasado, en Cuba y en Honduras, en la actualidad, como ya hemos visto. ${ }^{91} \mathrm{Al}$ igual que en el caso anterior (tropas en tránsito), los hechos internacionalmente ilícitos que se llegasen a presentar con ocasión de dicha presencia o acción extraterritorial, serían directamente imputables al Estado de origen, ${ }^{92}$ salvo que ciertos actos del Estado de acogida o recepción, o bajo su control, le fuesen imputables de manera independiente o autónoma, ${ }^{93} \mathrm{o}$ si los asumiese como propios. ${ }^{94}$

90 Aparte de su presencia en Estados asociados, en áreas propias o dependientes de ultramar, así como en territorio de otros Estados pertenecientes a la OTAN (Alemania, Bélgica, Dinamarca — Groenlandia - España, Reino Unido y territorios británicos del Océano Indico, Grecia, Islandia, Italia, Países Bajos, Portugal y Turquía), los Estados Unidos disponen de bases en el Medio Oriente (Arabia Saudita, Bahréin, Qatar y Yibuti) y en el Lejano Oriente (Corea del Sur y Japón), al igual que en Asia central (Kirguizistán) y en su confluencia con Europa (Kosovo).

91 Supra, I.B.1.

92 Es decir, a los Estados Unidos y no a Cuba o a Honduras, pues son los primeros, y no los dos últimos, quienes disponen del control sobre sus agentes.

93 Así, el proyecto de la CDI sobre la responsabilidad del Estado por hecho internacional ilícito establece en su artículo 19 que el capítulo sobre atribución "se entiende sin perjuicio de la responsabilidad internacional, en virtud de otras disposiciones de estos artículos, del Estado que cometa el hecho en cuestión o de cualquier otro Estado".

94 "El comportamiento que no sea atribuible al Estado en virtud de los artículos precedentes se considerará, no obstante, hecho de ese Estado según el derecho internacional en el caso y en la medida en que el Estado reconozca y adopte ese comportamiento como propio". Artículo 11 del PREHII. 
Así entonces, según el artículo 3o. del Anexo a la Resolución 3314 de la (XXXIV) Asamblea General de las Naciones Unidas, se considera como acto de agresión:

e) La utilización de fuerzas armadas de un Estado, que se encuentran en el territorio de otro Estado con el acuerdo del Estado receptor, en violación de las condiciones establecidas en el acuerdo o toda prolongación de su presencia en dicho territorio después de terminado el acuerdo.

Sin embargo, la posibilidad enunciada por la mencionada resolución se refiere especialmente a la eventualidad de que el Estado A aprovechara su presencia en el Estado B para agredirlo o para convertirse en una fuerza de ocupación. Empero, si se tratara de una agresión (invasión o ataque, bombardeo, bloqueo marítimo) del Estado A contra un determinado Estado C, sin que medie conocimiento o participación del Estado receptor (Estado B), la atribución del acto de agresión, así como la consecuente responsabilidad, incumbiría solamente al Estado de origen (Estado A).

Ahora bien, si el Estado B (receptor) conoce o facilita dicha agresión a partir de su territorio, por ejemplo, porque afirma compartir o tener el control soberano de su territorio - aunque no participe directamente en ella-, su omisión consciente podría conducir a cuestionar seriamente su responsabilidad en los actos del Estado de envío. Pero, en cualquier caso, habría que determinarse con exactitud la imputación de cada uno de los comportamientos constitutivos de dicho acto, con el objetivo de establecer la parte de responsabilidad que correspondería a cada sujeto involucrado.

En definitiva, en el plano internacional, el elemento trascendental es el del control, lo que nos permitirá finalmente abordar la última sección de este escrito.

2. Agresión igualmente imputable al Estado receptor

Tal y como lo presenta el Proyecto sobre responsabilidad y, la Resolución 3314, en particular, una agresión puede resultar tanto de una acción di- 
recta como de una omisión o comportamiento negligente. Es por ello que se hace necesario indagar sobre la eventual responsabilidad del Estado receptor en el caso de haber acogido sobre su territorio tropas extranjeras que cometerían un acto de agresión contra un tercero. Ahora, aunque las consecuencias pudieran ser las mismas, debemos distinguir entre aquellas situaciones de negligencia o connivencia (1), y aquellas de participación efectiva del Estado B en un acto de agresión llevado a cabo conjuntamente con el Estado que utiliza el territorio de B para agredir a un tercero (2).

\section{A. Facilitación del propio territorio para agredir a un tercero}

Dado que la agresión generalmente se trata de un hecho compuesto y de carácter continuo, habrá que analizar con mucho cuidado la eventual responsabilidad del Estado de acogida de tropas extranjeras. Así, resultaría más apropiado evaluar el caso concreto a la luz del Capítulo IV ("[r]esponsabilidad del Estado en relación con el hecho de otro Estado") del Proyecto sobre la REHII y, especialmente, la Resolución 3314, según la cual también constituirá acto de agresión: "f) La acción de un Estado que permite que su territorio, que ha puesto a disposición de otro Estado, sea utilizado por ese otro Estado para perpetrar un acto de agresión contra un tercer Estado".

Entendida como un hecho compuesto, habrá de examinarse cada uno de los elementos constitutivos, así como el momento de la agresión. Esto es:

[l]a violación por el Estado de una obligación internacional mediante una serie de acciones u omisiones, definida en su conjunto como ilícita, tiene lugar cuando se produce la acción u omisión que, tomada con las demás acciones u omisiones, es suficiente para constituir el hecho ilícito. ${ }^{95}$

Caso en el cual, "la violación se extiende durante todo el periodo que comienza con la primera de las acciones u omisiones de la serie y se 
prolonga mientras esas acciones u omisiones se repiten y se mantiene su falta de conformidad con la obligación internacional". ${ }^{96}$

Dicho de otra manera, la actuación del Estado que acoge sobre su territorio tropas extranjeras que, a su vez, habrían llevado a cabo un acto de agresión contra un tercer Estado, puede conducir a situaciones de responsabilidad del Estado B, independientemente de la responsabilidad que concierna al Estado A. Es decir, la agresión imputable en principio a este último, podría constituir un hecho compuesto, en el que de manera puntual o parcial, o temporalmente, participe el Estado B y, extenderse en el tiempo, así: "[l]a violación de una obligación internacional mediante un hecho del Estado que tiene carácter continuo se extiende durante todo el período en el cual el hecho continúa y se mantiene su falta de conformidad con la obligación internacional". ${ }^{97}$

Así las cosas, la utilización parcial o compartida de bases del Estado de acogida por el Estado de origen plantea situaciones muy delicadas para efectos de la imputación de un eventual acto de agresión contra un tercer Estado por parte del Estado A. Si el Estado B conserva, al menos teóricamente, el control o parte del mismo sobre sus propias bases militares, habría entonces que evaluar de manera cuidadosa si efectivamente es así o, si al contrario, no posee ningún tipo de dominio sobre las acciones de los agentes del Estado A. Un ejemplo bastante emblemático del problema en cuestión, lo constituye la crítica dirigida al Acuerdo de Cooperación Militar entre los Estados Unidos y Colombia (no aprobado), en el cual los primeros tendrían la posibilidad de utilizar seis bases aéreas del segundo. Pero, lo cierto es que la cooperación y el uso de instalaciones militares en Colombia por parte de los Estados Unidos datan de mucho tiempo atrás, y que su personal, tanto civil como militar, goza de inmunidad de jurisdicción y de ejecución. En ese sentido, el problema no sería hasta ahora sino de orden constitucional. ${ }^{98}$

96 Ibidem, artículo 15.2

97 Ibidem, artículo 14.2.

98 Desafortunadamente, en la demanda de inexequibilidad contra este acuerdo, la Corte Constitucional omitió tocar el fondo del asunto por estimar que hubo vicios de forma que afectaron su trámite y que deberían ser previamente subsanados. Supra, nota 65. 
Finalmente, la situación será mucho más clara — y grave — si el Estado receptor no solamente facilita su territorio, sino que además participa militarmente en dicho acto de agresión.

\section{B. Cuando el Estado participa o contribuye a la realización del ilícito}

Haciendo abstracción de una eventual agresión, directa y exclusivamente imputable a la acción del Estado B - aún con presencia de tropas extranjeras sobre su territorio-- es posible que éste contribuya de alguna forma con el Estado A para agredir al Estado C. Es decir, que tanto el Estado de las tropas de origen, como las del Estado receptor lleven a cabo una acción conjunta que, en caso de ilícito, nos acercaría más al concepto de coautoría y complicidad: "[e]l Estado que presta ayuda o asistencia a otro Estado en la comisión por este último de un hecho internacionalmente ilícito es responsable internacionalmente por prestar esa ayuda o asistencia". ${ }^{99}$

En dicho evento, el Estado de acogida, que presta la ayuda o asistencia, deberá responder por aquellos hechos que le son directamente imputables en caso de agresión; siempre y cuando lo haga "conociendo las circunstancias del hecho internacionalmente ilícito". ${ }^{100}$ Es decir, no basta con que el Estado B actúe en simple connivencia con el Estado A, o en violación de su deber de prevención, ${ }^{101}$ sino que debería participar de forma sustancial o decidida en el acto de agresión para que éste le sea imputable en la misma medida.

Otra situación muy diferente, y rara de imaginar, es que el Estado receptor tenga la dirección y el control de las tropas del Estado de origen en la comisión del hecho internacionalmente ilícito. En dicha suposición, el Estado A, simplemente sería el instrumento del Estado B, pero a quien se le imputaría efectivamente la agresión sería al Estado que dirige y controla, en la medida en que éste simplemente dispondría de las fuerzas

99 Ibidem, artículo 16.

100 Ibidem, artículo 16.a.

101 "La violación de una obligación internacional en virtud de la cual el Estado debe prevenir un acontecimiento determinado tiene lugar cuando se produce el acontecimiento y se extiende durante todo el período en el cual ese acontecimiento continúa y se mantiene su falta de conformidad con esa obligación”. Ibidem, artículo 14.3. 
armadas que se encontrarían a su servicio, convirtiendo a sus miembros, en realidad, en agentes del Estado B y no del Estado A, como se pretendería al inicio. ${ }^{102}$

No sobra pues, retomar los principios penales, ya que podría presentarse una situación similar al caso de la insuperable coacción, suponiendo que el Estado A, quien ha estacionado sus tropas en el territorio del Estado B, se vea obligado por éste último a cometer un acto de agresión. Difícil de imaginar también, pero de ser así, el Estado A tampoco podría invocar la coacción como causal de exclusión de ilicitud, al tratarse de una norma imperativa de carácter general, es decir, la prohibición de la agresión. ${ }^{103}$ Es por ello que el final del capítulo relativo a la imputación en el PREHII, se entiende "sin perjuicio de la responsabilidad internacional... del Estado que cometa el hecho en cuestión o de cualquier otro Estado". ${ }^{104}$

Basta de especulaciones: con todas las hipótesis imaginables intentaremos concluir en unos pocos párrafos.

\section{CONCLUSIÓN}

Aunque como amenaza potencial o no descartable, la instalación de bases militares en territorio extranjero no puede considerarse per se como un acto de agresión, por supuesto, sabemos que el factor de potencia militar juega un papel poco despreciable como estrategia de disuasión, lo que genera en muchas ocasiones el recelo y hasta la reacción violenta de quien se siente amenazado. Ahora, lo más importante para los Estados, tanto para aquellos que se sienten beneficiados, como para los que se sentirían amenazados con dicha presencia extranjera, es que los acuerdos o convenios de cooperación y, especialmente, aquellos relativos a la de-

102 "Se considerará hecho del Estado según el derecho internacional el comportamiento de una persona o de un grupo de personas si esa persona o ese grupo de personas actúa de hecho por instrucciones o bajo la dirección o el control de ese Estado al observar ese comportamiento”. Ibidem, artículo 8 o.

103 Supra, notas 1 y 85.

104 Artículo 19 del PREHII. 
fensa o asistencia militar y seguridad, se hagan en el respeto de la norma internacional y que se adopten las respectivas cláusulas de resolución de conflictos. A nuestra manera de ver, es la transparencia jurídica y el apego al Estado de derecho lo que permite, no solamente generar confianza, sino además, reducir las controversias de orden internacional y, desde luego, en caso de hecho ilícito, determinar con claridad el grado de responsabilidad que concierne a cada una de las partes involucradas, incluyendo a los individuos, como quedó establecido en Kampala.

En fin, si la lectura de este trabajo inspira algún consejo para los gobiernos, sería el de salvaguardar la coherencia de la política exterior, pues la línea entre la protección de interés nacionales y la intervención en asuntos internos de los demás Estados resulta ser a veces de una extrema delgadez. Pero, también resultará muy difícil sostener una crítica, cuando al mismo tiempo, o posteriormente, el autor de ella asume un comportamiento similar, lo que en DI se conoce como estoppel. ${ }^{105}$ En cualquier caso, los Estados deberían recordar con sumo interés que la competencia soberana que se desprende del elemento territorial no solamente puede ser vista como una potestad, sino también como una responsabilidad.

105 También conocida en derecho privado — de origen anglosajón- como el principio venire contra factum proprium non valet o "doctrina de los actos propios". 